\title{
Transepiteliales, usos, rehabilitación y complicaciones quirúrgicas, periodontales y protéticas
}

Luigi Franchella, Gianmarco Ruggiero, Silvia Martin Ortiz, María Bufalá Pérez, Sofía Hernández Montero, Universidad Alfonso X El Sabio.

\section{Introducción}

Para obtener buenos resultados en una rehabilitación protética es de vital importancia la función de los pilares que pasaron de ser una simple conexión entre el implante y la prótesis, a ser un determinante fundamental en el logro final estético y funcional del tratamiento rehabilitador. La presente revisión bibliográfica tiene como propósito analizar los pilares transepiteliales, sus usos y complicaciones quirúrgicas, periodontales y protéticas. La función principal de los pilares transepiteliales es facilitar soluciones protésicas de distintas índoles. Principalmente, sus dos grandes características son la capacidad de superficializar el eje de inserción del implante y corregir su angulación. La corrección de los desniveles y angulaciones en el arco dental es, en efecto, una de las funciones principales de los transepiteliales. Un ejemplo claro son los casos "All on four", en los que los implantes están colocados a $45^{\circ}$ y es necesario corregir el eje de la prótesis, lo que puede lograrse con un transepitelial.
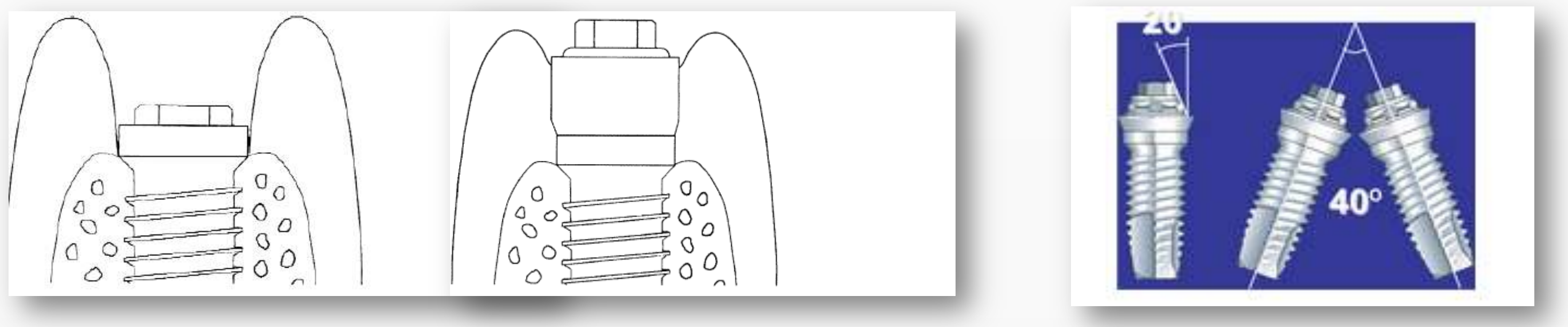

\section{Objetivos}

Los objetivos fueron determinar el uso y complicaciones de pilares transepiteliales, buscar soluciones protéticas, el uso en situaciones quirúrgicas y complicaciones periodontales.

\section{Resultados y Conclusiones}

Los pilares atornillados transepiteliales constituyen una excelente y sencilla solución para la confección de estructuras protéticas atornilladas, tanto en restauraciones completas como parciales, en casi cualquier situación clínica.

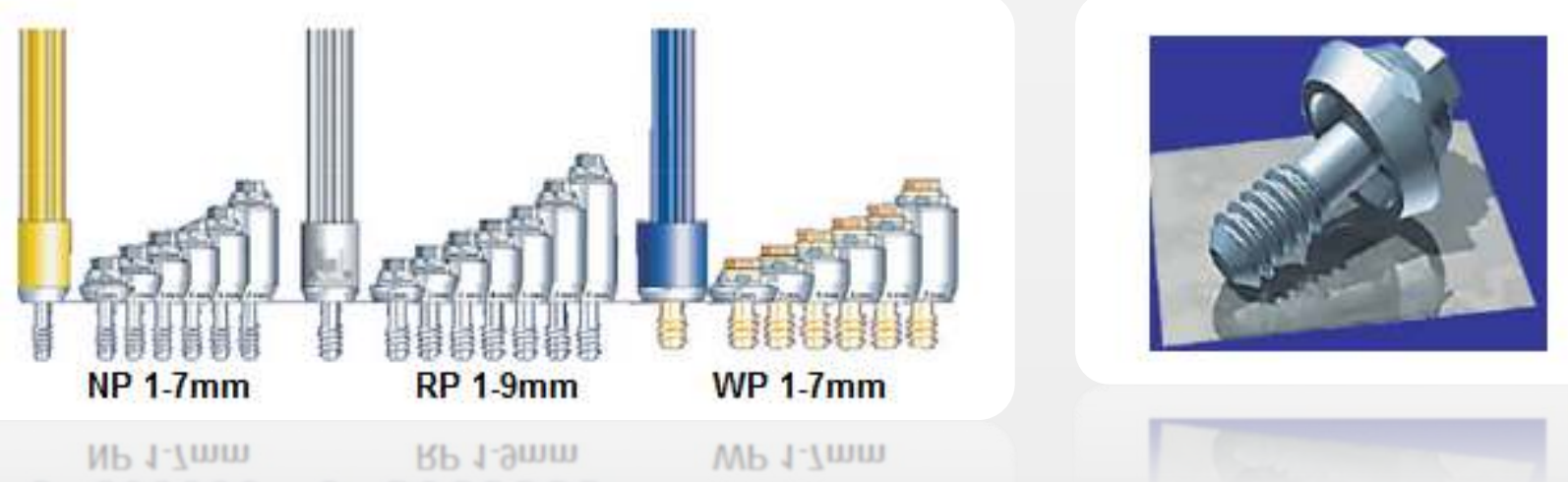

Por otro lado, reducen la necesidad de usar injertos óseos haciendo uso del hueso disponible y evitando al mismo tiempo estructuras anatómicas vitales, optimizando la eficiencia quirúrgica y paliando las molestias para el paciente.

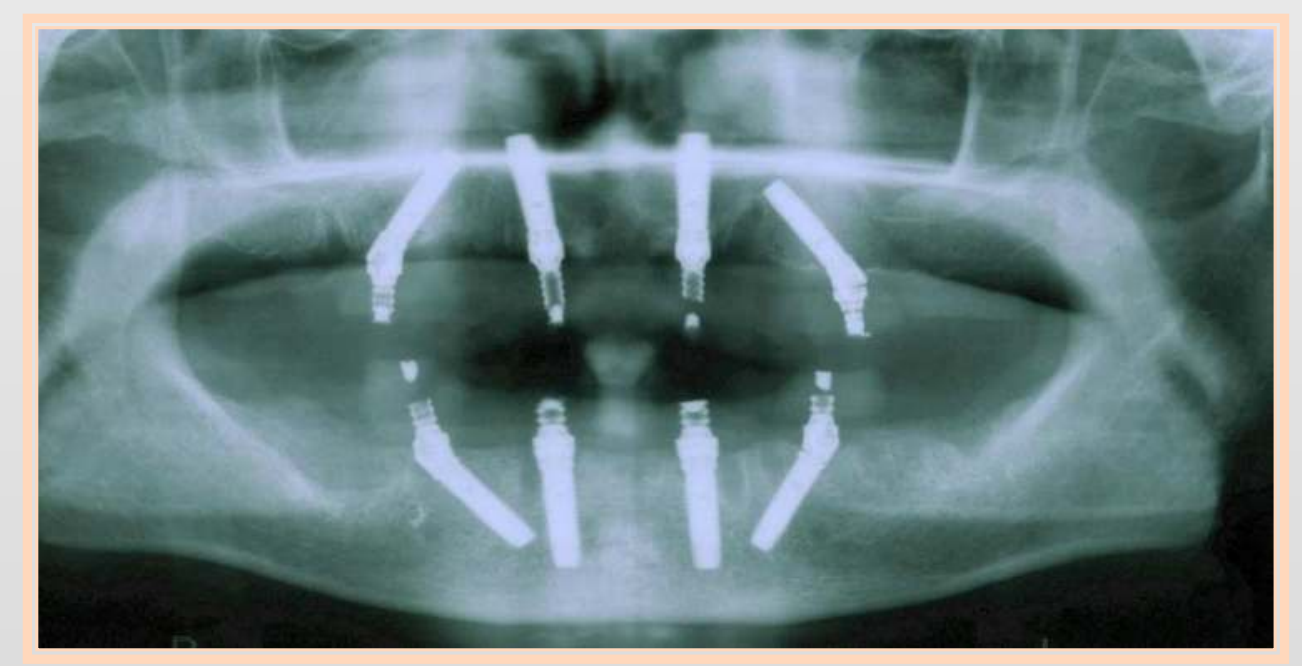

También mencionamos que las tensiones/deformaciones generadas a través de la carga fuera del eje implantario aumentan a medida que aumenta la angulación del pilar, pero no hay consenso en cuanto a qué grado de ángulación causará el fracaso del implante o perdida ósea.
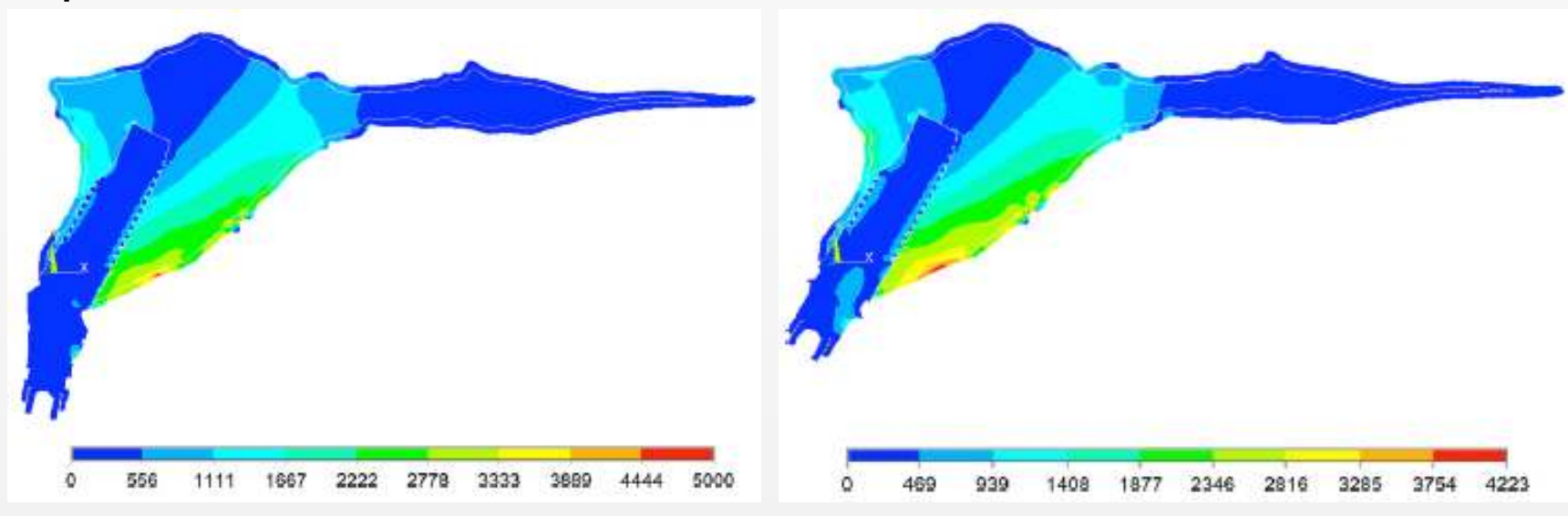

Finalmente destacar que el gap presente entre implate y pilar en conexiones internas y externas favorece la colonización bacteriana y puede terminar en enfermedad peri-implantaria si no es tratada.
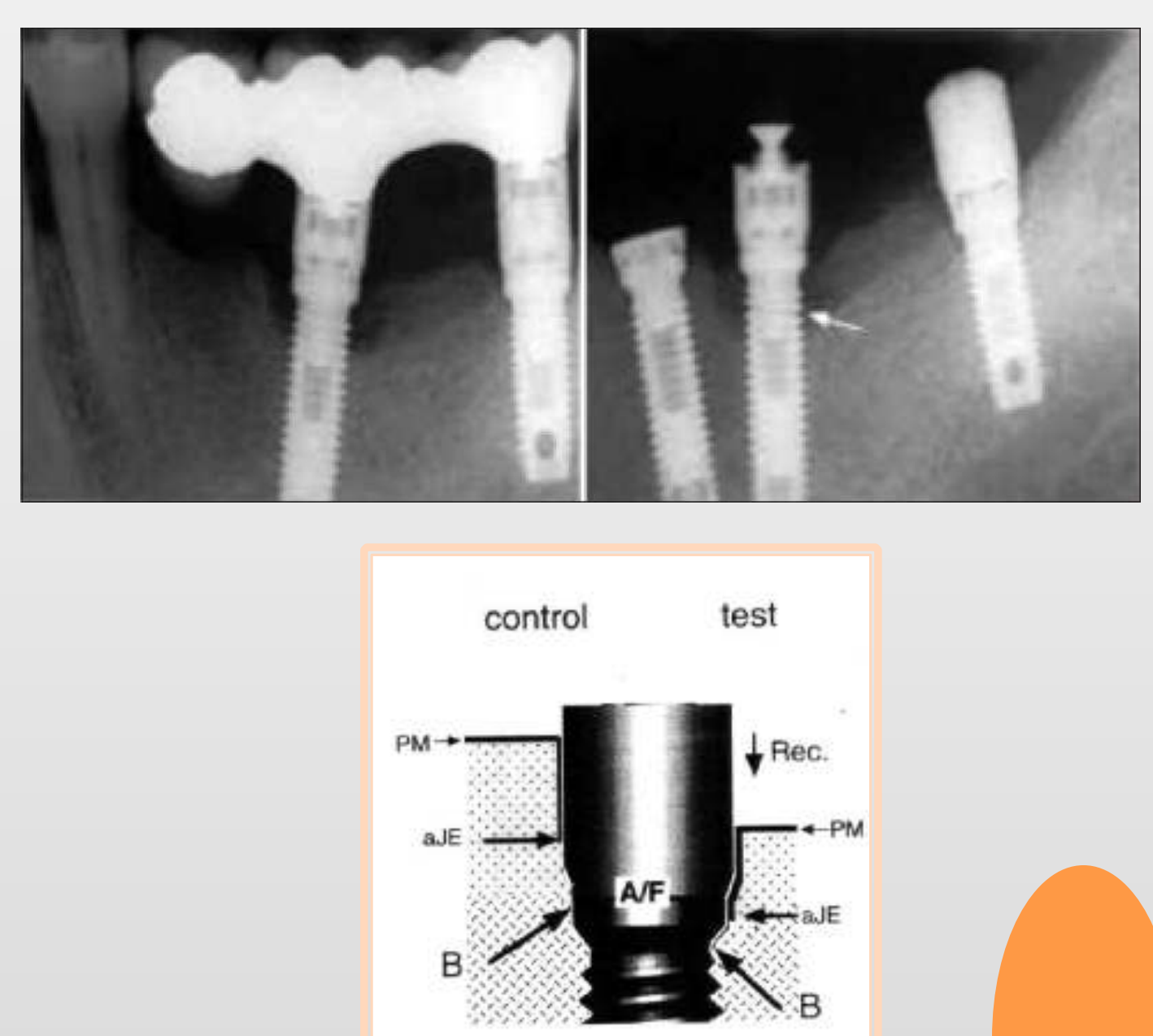

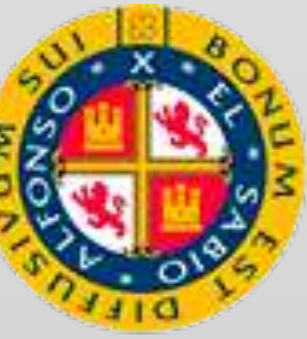

UNIVERSIDAD ALFONSO X EL SABIO
Copyright $\odot 2017$ Luigi Franchella

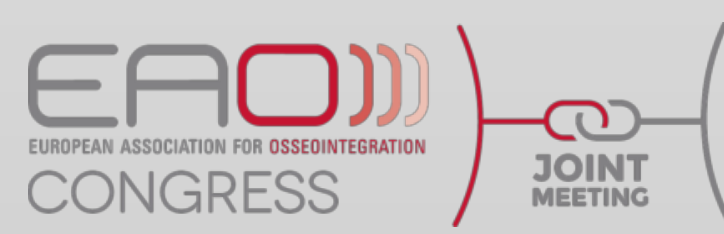

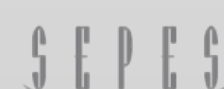

